\title{
The Role of Nutritional Factors in Asthma: Challenges and Opportunities for Epidemiological Research
}

\author{
Annabelle Bédard ${ }^{1, *(1)}$, Zhen $\mathrm{Li}^{2}{ }^{(1)}$, Wassila Ait-hadad ${ }^{1}$, Carlos A. Camargo Jr. ${ }^{3}\left(\mathbb{D}\right.$, Bénédicte Leynaert $^{1}{ }^{(\mathbb{D}}$, \\ Christophe Pison ${ }^{4}$, Orianne Dumas ${ }^{1} \mathbb{D}$ and Raphaëlle Varraso ${ }^{1}$ \\ 1 Université Paris-Saclay, UVSQ, University Paris-Sud, Inserm, Équipe d'Épidémiologie Respiratoire \\ Intégrative, CESP, 94807 Villejuif, France; wassila.ait-hadad@inserm.fr (W.A.-h.); \\ benedicte.leynaert@inserm.fr (B.L.); orianne.dumas@inserm.fr (O.D.); raphaelle.varraso@inserm.fr (R.V.) \\ 2 Clinical Research Centre, Shanghai First Maternity and Infant Hospital, Tongji University School of Medicine, \\ Shanghai 200092, China; zhen_li@tongji.edu.cn \\ 3 Department of Emergency Medicine, Massachusetts General Hospital, Harvard Medical School, \\ Boston, MA 02114, USA; ccamargo@partners.org \\ 4 Service Hospitalier Universitaire Pneumologie, Pôle Thorax et Vaisseaux, CHU Grenoble Alpes, \\ Laboratoire de Bioénergétique Fondamentale et Appliquée, Inserm 1055, Université Grenoble Alpes, \\ 38400 Grenoble, France; cpison@chu-grenoble.fr \\ * Correspondence: annabelle.bedard@inserm.fr
}

check for updates

Citation: Bédard, A.; Li, Z.; Ait-hadad, W.; Camargo, C.A., Jr.; Leynaert, B.; Pison, C.; Dumas, O.; Varraso, R. The Role of Nutritional Factors in Asthma: Challenges and Opportunities for Epidemiological Research. Int. J. Environ. Res. Public Health 2021, 18, 3013. https:// doi.org/10.3390/ijerph18063013

Academic Editor: Paul B. Tchounwou

Received: 28 January 2021

Accepted: 9 March 2021

Published: 15 March 2021

Publisher's Note: MDPI stays neutral with regard to jurisdictional claims in published maps and institutional affiliations.

Copyright: (c) 2021 by the authors. Licensee MDPI, Basel, Switzerland. This article is an open access article distributed under the terms and conditions of the Creative Commons Attribution (CC BY) license (https:// creativecommons.org/licenses/by/ $4.0 /)$.

\begin{abstract}
The prevalence of asthma has nearly doubled over the last decades. Twentieth century changes in environmental and lifestyle factors, including changes in dietary habits, physical activity and the obesity epidemic, have been suggested to play a role in the increase of asthma prevalence and uncontrolled asthma worldwide. A large body of evidence has suggested that obesity is a likely risk factor for asthma, but mechanisms are still unclear. Regarding diet and physical activity, the literature remains inconclusive. Although the investigation of nutritional factors as a whole (i.e., the "diet, physical activity and body composition" triad) is highly relevant in terms of understanding underlying mechanisms, as well as designing effective public health interventions, their combined effects across the life course has not received a lot of attention. In this review, we discuss the state of the art regarding the role of nutritional factors in asthma, for each window of exposure. We focus on the methodological and conceptual challenges encountered in the investigation of the complex time-dependent interrelations between nutritional factors and asthma and its control, and their interaction with other determinants of asthma. Lastly, we provide guidance on how to address these challenges, as well as suggestions for future research.
\end{abstract}

Keywords: asthma; asthma control; diet; physical activity; body composition; nutritional factors

\section{Introduction}

Asthma is a chronic inflammatory disease of the airways, affecting around 330 million individuals worldwide. Out of 359 diseases, asthma has been classified as the 30th and 32nd cause of disability-adjusted life years (DALYs) in females and males, respectively [1]. It is the most common chronic disease in children [2]. The prevalence of asthma has nearly doubled over the last decades, especially in Westernized countries and developing countries with rapid urbanization [3]. This cannot be explained by genetics alone and it has been hypothesized that this increase is a consequence of changing environmental and/or lifestyle factors [4]. Asthma control, which reflects the disease activity over a short period of time, is suboptimal in more than 50\% of adult patients in Europe [5], which has major consequences on health status, quality of life and economic burden [6]. In addition to primary prevention strategies, secondary public health interventions are therefore needed to control existing disease through early detection and appropriate treatment or to reduce the occurrence of exacerbations and the establishment of additional chronic conditions [7]. 
As recently underlined in The Lancet [8], given the immense societal and individual burden of asthma, there is an urgent need to further develop novel strategies to limit or even eradicate the disease. In this context, investigating the role of modifiable lifestyle factors (such as diet, physical activity and, consequently, body composition) is key for the primary and secondary prevention of this common disease. Twentieth century changes in dietary habits (less fruits/vegetables, more ready-to-eat meals), physical activity (less) and the obesity epidemic have been suggested to play a role in the increase of asthma prevalence and uncontrolled asthma worldwide [9]. A large body of evidence has suggested that obesity is a likely risk factor for asthma [10] but mechanisms are still unclear. It has been proposed that obese asthma represents a distinct phenotype of asthma, with one of its main characteristics being poor asthma control [11]. Regarding diet and physical activity, the literature remains inconclusive. Indeed, investigators examining nutritional factors (i.e., diet, physical activity and body composition) in asthma and its control face several challenges. Many definitions and approaches have been used in observational studies for the assessment of asthma and its control, as well as nutritional factors, which makes comparison of study findings a challenge [9]. Furthermore, the role of nutritional factors in asthma may vary throughout life and it is important to consider different windows of exposure. The investigation of the complex interrelations between nutritional factors and respiratory outcomes thus raises major methodological and conceptual challenges in terms of the interpretation and comparison of results, which might explain why definitive findings are scarce.

In this review, we discuss the issue of the assessment of asthma, asthma control and nutritional factors in epidemiological studies, and we provide a non-exhaustive review of the state of the art regarding the role of diet, physical activity and body composition in asthma and its control. Although we give a general overview of the current state of the literature on the role of nutritional factors in asthma for each window of exposure (antenatal period, childhood and adulthood), we focus more specifically on the importance of considering nutritional factors as a whole in this literature, and of addressing the methodological and conceptual challenges raised by the complex time-dependent interrelations between nutritional factors and asthma and its control, and their interaction with genetic, social, environmental and other lifestyle determinants of asthma. Lastly, we provide guidance on how to address these challenges, as well as suggestions for future research.

In this review, when referring to nutritional factors, we focused on the "diet, physical activity and body composition" triad (Figure 1), and when referring to diet, we focused on food/nutrient intake rather than specific dietary practices such as breastfeeding, infant feeding formula and processed/sterilized food consumption.

Glossary of terms (source: Oxford Languages dictionary)

Nutrition: Science that interprets the nutrients and other substances in food in relation to maintenance, growth, reproduction, health and disease of an organism. It includes ingestion, absorption, assimilation, biosynthesis, catabolism and excretion.

Diet: In nutrition, it is the sum of food consumed by a person.

Food: Any nutritious substance that people or animals eat or drink or that plants absorb in order to maintain life and growth.

Exercise: Any bodily activity that enhances or maintains physical fitness and overall health and wellness.

Physical activity: Any voluntary bodily movement produced by skeletal muscles that requires energy expenditure. It includes exercise and incidental activity integrated into daily activity.

Body composition: In physical fitness, it is used to describe the percentages of fat, bone, water and muscle in human bodies.

Obesity: Medical condition in which excess body fat has accumulated to an extent that it may have a negative effect on health. 
Asthma: Long-term inflammatory disease of the airways of the lungs, characterized by variable and recurring symptoms, reversible airflow obstruction, and easily triggered bronchospasms.

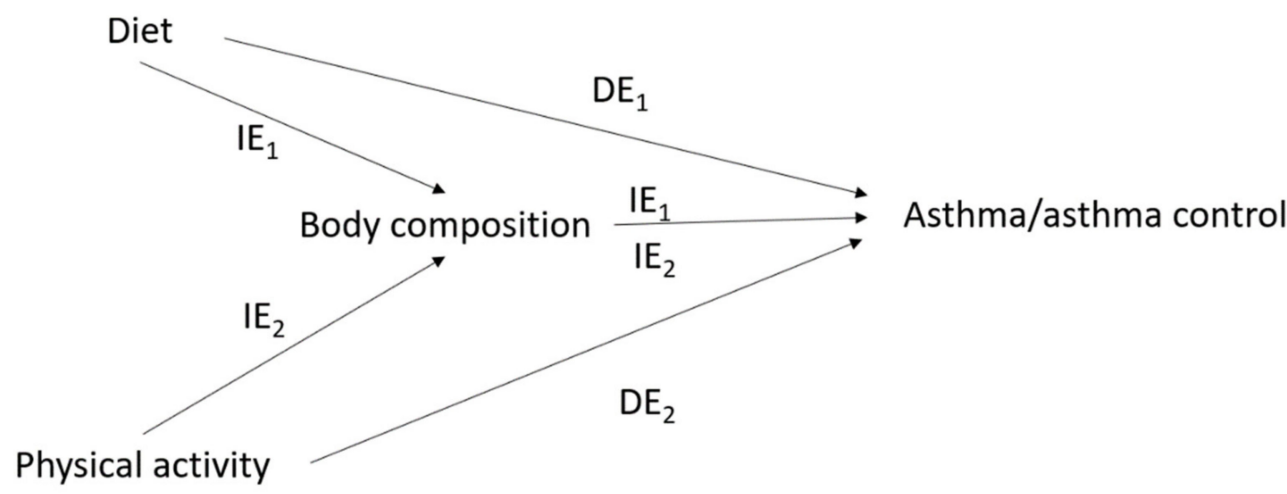

Figure 1. Issue of mediation* in the interrelations between nutritional factors and asthma/asthma control. $\mathrm{IE}_{1}=$ indirect effect of diet on asthma/asthma control mediated by body composition; $\mathrm{IE}_{2}=$ indirect effect of physical activity on asthma/asthma control mediated by body composition; $\mathrm{DE}_{1}=$ direct effect of diet on asthma/asthma control; $\mathrm{DE}_{2}=$ direct effect of physical activity on asthma/asthma control; ${ }^{*}$ For simplicity, the time-dependent nature of the interrelations between nutritional factors and asthma, and their covariates, is not represented in this figure (see Figure 2).

\subsection{Assessment of Asthma and Asthma Control in Epidemiological Studies}

Asthma is a complex and heterogeneous disease that involves multiple phenotypes or endotypes and windows of expression [12]. Asthma incidence during childhood is greater in boys than in girls, whereas after puberty, asthma incidence is greater in women than in men and remains higher throughout the reproductive years [13]. Early-onset asthma is more often allergic as compared to late-onset asthma. Asthma in the elderly is characterized by more frequent irreversible airway obstruction and accelerated lung function decline due to airway remodeling and sometimes co-existing chronic obstructive pulmonary disease (COPD) as the so-called asthma-COPD overlap (ACO), which was first introduced by the Dutch hypothesis in $1961[14,15]$. The clinical expression of asthma and its control varies over time, both from a long-term perspective (e.g., asthmatic patients may experience periods of remission, sometimes followed by a relapse of symptoms [16]) and from a short-term perspective (e.g., asthma control fluctuates, which can partly be explained by exposure to asthma "triggers" such as tobacco smoke, pets, dust, mites, season, etc.).

Given its phenotypic heterogeneity, the assessment of asthma is challenging. In most epidemiological studies, childhood asthma is assessed using standardized questionnaires on respiratory symptoms, and wheezing patterns during childhood have been proposed as phenotypes of interest [17]. Standardized questionnaires have also been widely used in epidemiological studies to assess asthma incidence or prevalence in adulthood, most of the time using a dichotomous definition such as the doctor-diagnosed asthma definition from the American Thoracic Society standardization project [18], or the British Medical Research Council (BMRC) definition [19]. However, using a dichotomous definition for such a highly heterogeneous and underdiagnosed disease as asthma, particularly when the doctor-diagnosed asthma definition is used, might lead to misclassification and biased estimates of the investigated associations. In this context, the asthma symptom scorea multi-categorical measure based on several asthma symptoms- has been proposed to study risk factors of asthma in longitudinal studies [20,21]. The asthma symptom score additionally allows for the detection of changes in asthma symptoms over time, reflecting either asthma incidence or remission, relapse or persistence of the disease among participants with asthma. Objective measures of variable expiratory airflow limitation (e.g., lung function with reversibility test, bronchial hyperresponsiveness) and atopic status 
(specific Immunoglobulin E (IgE), skin prick tests) are key features of asthma diagnosis in clinical practice. However, they are rarely available in epidemiological studies, particularly in the case of large cohort studies, and when they are, it is not clear which combination of objective measures should be used [6].

Most studies on asthma control are clinical studies and few epidemiological studies in large populations have assessed asthma control in a comprehensive manner. Several composite assessment instruments have been developed to measure asthma control. The childhood asthma control test (CACT) is a validated tool that has been widely used to assess asthma control in children aged 4 to 11 years old [22]. Regarding asthma control in adulthood, the asthma control test (ACT) and the asthma control questionnaire (ACQ), which are both derived using information on symptom frequency, rescue therapy use, sleep interference and activity limitation (the ACT covers the preceding month, whereas the ACQ covers the preceding week and additionally requires spirometry measures), have been proposed by experts as the most appropriate standardized composite scores [23].

\subsection{Assessment of Nutritional Factors in Epidemiological Studies}

Regarding the assessment of diet in nutritional epidemiology, studies on specific foods or nutrients have traditionally been conducted. However, several conceptual and methodological limitations have been raised [24] as people do not consume isolated foods or nutrients, but meals consisting of a complex combination of foods, which themselves contain nutrients that possibly interact with each other and make it difficult to disentangle their isolated/joint effects. Another problem, when investigating the simultaneous effects of different foods, is that statistically significant associations can more easily occur by chance, thus raising the need to account for multiple testing. For these reasons, studying dietary patterns, which are data-driven methods, and dietary scores, which are based on prevailing hypotheses and guidance about the role of nutrients or foods in disease prevention, has been proposed in order to study the effects of overall diet, rather than the effects of specific foods or nutrients. Many dietary scores have been proposed; the most widely used in respiratory epidemiology are the Mediterranean diet score [25] and the international Alternate Healthy Eating Index 2010 (AHEI-2010) [26], which evaluate the effects of overall diet quality. Other dietary scores have been proposed to assess specific biological properties of diet, such as the dietary total antioxidant capacity (TAC) [27] and the dietary inflammatory index (DII) [28]. Another challenge in nutritional epidemiology is the method used to collect dietary data. Three methods have been the most extensively used: (1) the short-term 24-hour recall and (2) diet record methods, which both allow for greater specificity and accuracy [29]; and (3) the food-frequency questionnaire (FFQ) method, which decreases the error of day-to-day consumption and shows overall good reproducibility and validity despite introducing errors caused by averaging over long time intervals [30].

To assess physical activity, most epidemiological studies have primarily relied on self-reported questionnaires. Although no standardized approach exists, the self-completed international physical activity questionnaire (IPAQ) - which provides information on the time spent walking, in vigorous- and moderate-intensity activity and in sedentary activity, as well as additional information on household and yard work activities, occupational activity and self-powered transport (for the long version of the questionnaire)- has been validated previously in multiple international settings and population groups [31]. Using information from self-reported questionnaires, physical activity can be estimated by multiplying the metabolic equivalent of task (MET) cost of each activity by their frequency and duration, following the official IPAQ scoring protocol [32]. Nevertheless, physical activity is best evaluated objectively by accelerometers, which are wearable monitor devices that measure multiaxial accelerations of the body segment to which they are attached, thus enabling the estimation of the amount of sedentary and physical activity time [33]. Accelerometers offer a valid, objective alternative to self-reported questionnaires, which 
suffer from recall bias, measurement error and insufficient validity [34], although their use in population-based or longitudinal studies may be less feasible.

Body mass index (BMI in kilograms per square meter), with thresholds proposed by the World Health Organization or the U.S. Centers for Disease Control and Prevention to define underweight, overweight and obesity in adulthood and childhood [35,36], respectively, is widely used in epidemiological studies to evaluate body composition, because weight and height can be assessed quite accurately, even by self-reporting [37]. However, the use of BMI in epidemiological studies does not allow researchers to distinguish between fat mass and lean body mass [38]. For instance, two persons with the same BMI may have different proportions of fat free mass and fat mass, and a higher fat mass/lean mass ratio is likely to have more adverse metabolic effects. Indeed, a recent study has suggested that studying body compartments is more relevant when assessing the effects of obesity on lung function and growth in children [39]. Several methods have been developed to measure fat mass and lean body mass, including densitometry [40] or dual-energy X-ray absorptiometry (DEXA) [41], and more recently, bioelectrical impedance analysis (BIA) [42], which is more easily applicable to epidemiological studies, but may not be superior to $\mathrm{BMI}$ as a predictor of overall adiposity in a general population [43]. Several alternative ways have been proposed to measure adiposity in epidemiological studies, such as the calculation of waist and hip circumference (and their ratio), skinfold measurements [38], or the use of body silhouette pictograms [44].

\section{The Role of Nutritional Factors in Asthma and Asthma Control: State of the Art}

Nutritional factors evolve throughout life and may thus influence asthma and its control in different ways and by different mechanisms according to the window of exposure. It is thus crucial to make the distinction between the prenatal period, childhood and adulthood when comparing findings from the literature. The bulk of research investigating nutritional factors in asthma and asthma control has focused on a single nutritional factor, while considering the other nutritional factor(s) as potential confounders (when available). In the next section, we give a general overview (i.e., a non-exhaustive review) of the scientific literature on each nutritional factor and asthma and asthma control, distinguishing findings by windows of exposure (antenatal/childhood/adulthood) and by outcomes (asthma versus asthma control).

\subsection{Diet and Asthma and Its Control}

\subsubsection{Asthma}

Evidence for a protective role of maternal intake of vitamins E and D, zinc, fruits, vegetables, omega-3 polyunsaturated fatty acids (PUFAs) or an overall healthy diet (assessed using the Mediterranean diet score or a negative DII score) during pregnancy has been found with regard to the risk of wheezing in the first years of life [45-50], but evidence for a lower risk of actual asthma, or even wheezing later in childhood, is lacking [45-48,51,52]. Recent studies have suggested a protective effect of maternal iron supplementation [53] and deleterious effects of high maternal free sugar, fructose and sugar-sweetened beverage (SSB) intake [54,55] and of a pro-inflammatory diet [56] during pregnancy on asthma development in mid- or late-childhood.

Many studies have investigated the role of diet during childhood, but very few studies were longitudinal. The association between diet and childhood asthma is moderate at best, with observational studies reporting 'protective' associations for fruits and vegetables and fish intake $[45,57,58]$. In recent years, several studies-including one longitudinal study - have suggested a deleterious effect of high fructose and SSB intake on asthma development [55]. Very few longitudinal studies have investigated the association between dietary patterns and childhood asthma, including one suggesting a deleterious effect of a Western diet (i.e., a high intake of refined grains, savory and snacks, sugar-containing beverages, meat, etc.), derived using principal component analysis (a data-driven approach), on wheeze incidence [59]. 
Few longitudinal studies have investigated the role of diet during adulthood. The association between diet and adult asthma is moderate at best, with observational studies reporting 'protective' associations for fruits and vegetables and vitamin E $[57,60]$. Recent studies using the asthma symptom score as a continuous definition of asthma have shown evidence for a role of diet at the nutrient level (a protective role of high fiber intake [61]), at the food level (a deleterious role of high processed meat intake $[62,63]$ ) and at the dietary score level (a protective role of a healthy diet $[64,65]$ ), whereas no evidence was found using a binary definition for asthma [66-68]. In recent years, several studies-including one longitudinal study—suggested a deleterious effect of SSB intake on asthma [69].

\subsubsection{Asthma Control}

The Global Initiative for Asthma Guidelines encourages patients with asthma to consume a diet high in fruit and vegetables for its general health benefits [6]. But to date, the role of diet as a disease modifier remains underexplored. In children, a few studies reported that higher serum levels of $25(\mathrm{OH}) \mathrm{D}$ may be associated with a reduced risk of asthma exacerbations [70], whereas no evidence for a role of PUFAs on asthma control has been found so far in children or adults [60]. In adults, evidence was found for a deleterious effect of the 'Western' dietary pattern on asthma attack frequency [71] and asthma control [72], for a protective effect of a 'nuts and wine' pattern on asthma attack frequency [71] and for a protective effect of the "Prudent" pattern (i.e., characterized by a high intake of fruits, vegetables, whole grains, legumes, etc.) and healthy dietary scores on asthma control [65,72], whereas the evidence regarding the effect of the Mediterranean diet on asthma control was conflicting [73,74]. More recently, a pilot randomized controlled trial (RCT) reported better asthma control after a 6-month healthy eating intervention based on the Dietary Approaches to Stop Hypertension (DASH) score [75].

\subsection{Physical Activity and Asthma and Its Control}

\subsubsection{Asthma}

Only a few longitudinal studies have been conducted on the role of physical activity in asthma development, suggesting overall a protective effect both in children and in adults, but studies are very heterogeneous in terms of the assessment of asthma and physical activity [76,77]. Moreover, reverse causation is a major limitation in the investigation of the role of physical activity in asthma development.

\subsubsection{Asthma Control}

Despite national and international guidance to increase exercise, patients with asthma are less likely to engage in physical activity, partly due to the risk of exercise-induced bronchoconstriction (EIB). Although some intervention studies of exercise as a diseasemodulating treatment have suggested clinical improvements for obese and non-obese patients with asthma, and exercise is encouraged in current treatment guidelines, there are no specific recommendations as to the intensity, frequency or duration of exercise exposure. This research is urgently needed so that more specific physical activity recommendations can be developed for children and adults with asthma [78-80].

\subsection{Body Composition and Asthma and Its Control \\ 2.3.1. Asthma}

Obesity is now an established risk factor for asthma [10,81]. Regarding windows of exposure, although several studies have suggested that a high BMI during childhood may predict a risk of developing asthma in adulthood [82], others have suggested that being overweight early in life may not have a long lasting effect on childhood asthma, if the child develops a normal weight later on [83]. Other studies concluded that a high BMI in adulthood, or an increase in body silhouette between menarche and adulthood, is related to the incidence of asthma later in life [84]. Although a low birth weight has been associated with childhood asthma [85], a recent meta-analysis points to the deleterious effect of both 
pre-pregnancy maternal obesity or overweight and high or low gestational weight gain on the childhood asthma risk in the offspring [86], supporting the early origins hypothesis for asthma. Further longitudinal studies accounting for the tracking of body composition from pregnancy to adulthood are thus needed [85]. Although the direction of the obesity-asthma association has been established for a long time (i.e., obesity preceding asthma) [87], a few recent studies have suggested that asthma may also precede childhood obesity $[88,89]$. A number of studies have then used Mendelian randomization (i.e., an approach using genetic variants to assess causal relationships, which can be regarded as a 'natural' RCT) to test the bi-directional association between obesity and asthma. Although these studies support the hypothesis that obesity is causally related to asthma, they did not find evidence supporting the causal role of asthma on obesity.

\subsubsection{Asthma Control}

A review of 11 studies reported an overall positive association between obesity and worse asthma control in asthma patients [11]. The obesity-asthma control association has been further strengthened by consistent findings showing that weight reduction in obese patients with asthma, through bariatric surgery or not, was associated with improvement in multiple asthma-related outcomes, including asthma control [90].

In brief, published papers investigating nutritional factors in asthma and its control are heterogeneous in terms of the conceptual definition and assessment of both the outcomes and the exposures, and in terms of the window of exposure, which may explain why much of this literature remains inconclusive.

\subsection{The Complex Interrelations between Nutritional Factors and Asthma and Its Control}

Although each of the three nutritional factors has individually been associated with asthma or asthma control in longitudinal studies for different windows of exposure, their combined effects across the life course has not received a lot of attention. However, the investigation of nutritional factors as a whole (e.g., the Western lifestyle) is highly relevant in terms of understanding underlying mechanisms, as well as designing effective public health interventions.

Several shared mechanisms have been proposed to explain the role of each nutritional factor on asthma and its control, including oxidative stress and inflammation, and more recently, imbalance in the gut microbiome. Indeed there has been an exponential increase in the evidence-mainly from animal studies-linking the gut microbiota's dysbiosis with diseases such as obesity and asthma [91] and with dietary [92] and exercise [93] interventions, and evidence of a lung-gut microbiome axis [94-96]. Other specific mechanisms have been suggested to explain the role of nutritional factors in asthma and its control, such as mechanical or hormonal mechanisms or via comorbidities, concerning obesity [97]; the modulatory effect of sigh rate on smooth muscle function and bronchoconstriction, concerning a sedentary lifestyle [98] and physical activity [99]; and epigenetic modification [100] or vitamin D pathways, concerning diet [101]. It is thus particularly relevant to identify and distinguish possible shared and specific mechanisms and pathways that may underlie the complex interrelations between diet, physical activity, body composition and asthma across the life course. For example, the effect of low physical activity or unhealthy diet on asthma could partly be mediated by the inflammatory effect of fat mass and adipokines (an indirect effect via body composition), in addition to a direct effect through other specific mechanisms (e.g., the deleterious effect of a sedentary lifestyle on bronchoconstriction or epigenetic modulation from the diet). 
A few interventional studies in asthma have considered more than one nutritional factor [102]. Among them, one RCT conducted among 330 obese adults with uncontrolled asthma, targeting modest weight loss (i.e., of 7-10\%) through a 12-month intervention based on healthy-eating counseling with calorie reductions (but no specific dietary pattern) and moderate-intensity physical activity did not report evidence for a significant overall benefit for asthma control (although weight loss of $10 \%$ or greater was associated with improved asthma control) [103]. In contrast, another RCT conducted among 125 non-obese patients with asthma, targeting a high protein, low glycemic index, anti-inflammatory diet, and high-intensity interval training on indoor spinning bikes over 8 weeks reported improved asthma control and asthma-related quality of life [104]. However, interventional studies usually have a relatively short follow-up that does not allow us to make any long-term inferences, and most dietary intervention studies either focus on the effect of a specific nutrient or target relatively strict calorie reductions, and thus do not allow for the examination of lifestyle interventions that are realistically achievable in terms of public health. Observational studies are thus crucially needed to overcome these limitations. To date, few observational studies have investigated the joint roles of diet, physical activity and/or body composition as determinants of asthma, either by simply considering each nutritional factor as an independent exposure [105-112], or by creating a combined score of "unhealthy behaviors" (e.g., unhealthy weight, high processed meat intake, unhealthy overall diet and smoking) $[63,113]$, but most of them do not properly address the methodological challenges that are inherent to the investigation of the role of nutritional factors in asthma. For example, one of these studies, which was a large cross-sectional study conducted in children from eight Spanish cities, suggested independent protective effects of the Mediterranean score and exercise and a deleterious effect of obesity with regards to current asthma [105]. However, the possible independent effect of each risk factor was assessed using standard regression models, adjusting one nutritional factor for the other, leading to the issue of over-adjustment. Another study assessed the interrelations between obesity, physical fitness, sedentary time and asthma incidence among children using generalized equation analysis and a structural equation model [112], suggesting that low physical fitness levels and high screen time leads to central obesity, which leads to asthma development. Although the study was longitudinal (in terms of associations between nutritional factors and childhood-onset asthma), interrelations between physical fitness level, sedentary time and central obesity were analyzed in a cross-sectional manner, leading to the issue of time-dependent confounding.

2.4.1. The Issue of Mediation in the Interrelations between Diet, Physical Activity, Body Composition and Asthma

One major methodological challenge in the investigation of nutritional factors in asthma comes from the fact that diet, physical activity and body composition are lifestyle factors that are closely interrelated (overweight and obesity reflect an imbalance between energy provision-i.e., intake of calories - and expenditure-i.e., physical activity), which makes it difficult to disentangle their separate effects on a health outcome. In particular, body composition might mediate potential effects of diet or physical activity on an obesity-related disease, such as asthma (Figure 1). Previous statistical and epidemiological research has shown that adjusting for a mediator (e.g., obesity) and a common cause (e.g., physical activity) of the mediator and the outcome, when assessing the causal association between an exposure (e.g., dietary habits) and an outcome (e.g., asthma), leads to biased results $[114,115]$. Despite the complex interrelationships within nutritional factors, obesity (or BMI) has usually been considered as a confounder in studies investigating the association between diet/physical activity and obesity-related diseases, raising the issue of potential over-adjustment. 
Over the past 30 years, there have been important developments in causal theories, and novel approaches from the causal inference framework are now widely recommended to limit bias in epidemiological studies. In particular, the counterfactual approach (counterfactuals are defined as the outcome that would have been observed, had the exposure differed) in mediation analysis, has been proposed to tackle the issue of potential mediation by body composition in the effects of diet and physical activity on asthma $[116,117]$. These approaches enable researchers to distinguish and estimate the overall effect of the exposure on the disease (i.e., total effect), the effect passing through the mediator (i.e., indirect effect) and the effect unexplained by the mediator (i.e., direct effect) (Figure 1). Several epidemiological studies have used mediation analysis from the causal inference framework in the context of respiratory health [62,64,118-122], including studies on obesity and asthma [118], on obesity and lung function [119] and on physical activity and lung function [120]. One recent study was conducted to investigate potential mediation by obesity in the association between diet and healthy aging [123]. To our knowledge, only two studies were conducted in the context of nutritional factors and asthma, suggesting that BMI partly mediates the association between high cured meat intake and worsening asthma symptoms over time [62], but does not mediate the association between overall diet quality-assessed using the AHEI-2010—and improved asthma symptoms [64] (see Table 1). 
Table 1. Studies that used methods from the causal inference framework to investigate associations between nutritional factors and asthma.

\begin{tabular}{|c|c|c|c|c|c|c|}
\hline Reference & Population & Design & Outcome & Exposures & Results & Comments \\
\hline $\begin{array}{l}\text { Li Z et al., } \\
\text { Thorax } 2017\end{array}$ & $\begin{array}{l}971 \text { adults from the } \\
\text { French prospective } \\
\text { EGEA } \\
\text { case-control study } \\
\text { (baseline: 2003-2007; } \\
\text { follow-up: 2011-2013) }\end{array}$ & $\begin{array}{l}\text { Mediation analysis in the } \\
\text { counterfactual } \\
\text { framework to estimate } \\
\text { the direct effect of } \\
\text { baseline cured meat } \\
\text { intake on change in } \\
\text { asthma symptom over } \\
\text { follow-up, and the } \\
\text { indirect effect mediated } \\
\text { by BMI at baseline }\end{array}$ & $\begin{array}{l}\text { Change in asthma } \\
\text { symptom score } \\
\text { (calculated at each } \\
\text { time-point using } \\
\text { information as sum of } \\
5 \text { respiratory asthma } \\
\text { symptoms in the last } \\
12 \text { months) categorized } \\
\text { as 'stable/improved' } \\
\text { or 'worsening' }\end{array}$ & $\begin{array}{l}\text { Cured meat intake (<1, 1-3.9, } \\
\geq 4 \text { servings/week) estimated } \\
\text { using information on average } \\
\text { dietary intakes during the } \\
\text { previous } 12 \text { months of ham, } \\
\text { dried sausage and sausage } \\
\text { consumption (from a 118-item } \\
\text { semi-quantitative } \\
\text { food-frequency } \\
\text { questionnaire (FFQ) } \\
\text { based on a French validated } \\
\text { dietary questionnaire) } \\
\text { BMI: calculated using } \\
\text { measures of height and weight }\end{array}$ & $\begin{array}{l}\text { Positive direct effect of } \\
\text { cured meat intake on } \\
\text { worsening asthma } \\
\text { symptoms: } \\
\text { multivariable odds ratio } \\
(\text { OR) }=1.76 \text { ( } 95 \% \text { CI: } 1.01 \text {, } \\
3.06) \text { for } \geq 4 \text { vs. }<1 \\
\text { serving/week } \\
\text { Positive indirect effect } \\
\text { mediated by BMI: } \\
\text { OR=1.07 (1.01, } 1.14) \text { for } \\
\geq 4 \text { vs. }<1 \text { serving/week, } \\
\text { accounting for } 14 \% \text { of } \\
\text { the total effect }\end{array}$ & $\begin{array}{l}\text { Physical activity at } \\
\text { baseline, expressed in } \\
\text { metabolic equivalents } \\
\text { (METS)/ week, was } \\
\text { considered as potential } \\
\text { confounder and thus } \\
\text { adjusted for in } \\
\text { the models }\end{array}$ \\
\hline $\begin{array}{l}\text { Li Z et al., } \\
\text { Br J Nutr } 2017\end{array}$ & $\begin{array}{l}969 \text { adults from the } \\
\text { French prospective } \\
\text { EGEA case-control study } \\
\text { (baseline: 2003-2007; } \\
\text { follow-up: 2011-2013) }\end{array}$ & $\begin{array}{l}\text { Mediation analysis in the } \\
\text { counterfactual } \\
\text { framework to estimate } \\
\text { the direct effect of } \\
\text { baseline AHEI score on } \\
\text { change in asthma } \\
\text { symptom over } \\
\text { follow-up, and the } \\
\text { indirect effect mediated } \\
\text { by BMI at baseline }\end{array}$ & $\begin{array}{l}\text { Change in asthma } \\
\text { symptom score } \\
\text { (calculated at each } \\
\text { time-point using } \\
\text { information as sum of } 5 \\
\text { respiratory asthma } \\
\text { symptoms in the last } 12 \\
\text { months) categorized as } \\
\text { 'stable/improved' } \\
\text { or 'worsening' }\end{array}$ & $\begin{array}{l}\text { The AHEI-2010 dietary score } \\
\text { (range 0-10 based on high } \\
\text { intake of vegetables, fruits, } \\
\text { whole grains, nuts and } \\
\text { legumes, long-chain n-3 fatty } \\
\text { acids and PUFA; moderate } \\
\text { intake of alcohol; and low } \\
\text { intake of sugar-sweetened } \\
\text { drinks and fruit juice, red/ } \\
\text { processed meat, trans-fat and } \\
\text { Na), estimated using } \\
\text { information from a 118-item } \\
\text { semi-quantitative FFQ based } \\
\text { on a French validated dietary } \\
\text { questionnaire } \\
\text { BMI: calculated using } \\
\text { measures of height and weight }\end{array}$ & $\begin{array}{l}\text { - Among never smokers: } \\
\text { positive total effect } \\
\text { (multivariable OR }=1.39 \\
{[1.07,1.80] \text { and }} \\
\text { positive direct effect } \\
\text { (OR }=1.41[1.09,1.80] \text { of } \\
\text { the AHEI-2010 (per } \\
\text { ten-point increment) on } \\
\text { improved symptoms; no } \\
\text { indirect } \\
\text { effect mediated through } \\
\text { BMI (OR=0.99 } \\
\text { [0.91, 1.07]). } \\
\text { - Among former and } \\
\text { current smokers: no } \\
\text { statistically significant } \\
\text { effect }\end{array}$ & $\begin{array}{l}\text { Physical activity at } \\
\text { baseline, expressed in } \\
\text { metabolic equivalents } \\
\text { (METS)/ week, was } \\
\text { considered as potential } \\
\text { confounder and thus } \\
\text { adjusted for in } \\
\text { the models }\end{array}$ \\
\hline
\end{tabular}


Table 1. Cont.

\begin{tabular}{|c|c|c|c|c|c|c|}
\hline Reference & Population & Design & Outcome & Exposures & Results & Comments \\
\hline $\begin{array}{l}\text { Bédard A et al., } \\
\text { Am J Epidemiol } 2017\end{array}$ & $\begin{array}{l}15,353 \text { adult women } \\
\text { from the Asthma-E3N } \\
\text { case-control study } \\
\text { (nested within the } \\
\text { French E3N cohort) with } \\
\text { data collected at least } 4 \\
\text { times between } 1997 \\
\text { and } 2011\end{array}$ & $\begin{array}{l}\text { Marginal structural } \\
\text { models (MSMs) } \\
\text { considering three time } \\
\text { periods: } t-1 / t / t+1 \\
(1997 / 2000 / 2002, \\
2000 / 2002 / 2005, \\
\text { and } 2002 / 2005 / 2011) \\
\text { with BMI and physical } \\
\text { activity at time } t \text {, current } \\
\text { asthma at time } t+1 \text {, } \\
\text { and covariates } \\
\text { at time } t-1 \text { or baseline }\end{array}$ & $\begin{array}{l}\text { Current asthma: } \\
\text { asthma attacks } \\
\text { and/or asthma } \\
\text { treatment (inhaled } \\
\text { bronchodilators } \\
\text { or inhaled } \\
\text { corticosteroids) in the } \\
\text { last } 12 \text { months } \\
\text { (self-report) }\end{array}$ & $\begin{array}{l}\text { BMI: calculated using } \\
\text { self-reported height and } \\
\text { weight } \\
\text { Physical activity: expressed in } \\
\text { metabolic equivalent } \\
\text { of task (MET)-hours per week } \\
\text { using self-reported amount of } \\
\text { time spent doing different } \\
\text { activities. All } \\
\text { MET-hours/week values were } \\
\text { added and categorized in } \\
\text { tertiles (low/moderate /high } \\
\text { level of physical activity) }\end{array}$ & $\begin{array}{l}\text { - Strong significant and } \\
\text { positive dose-response } \\
\text { relationship } \\
\text { between BMI and } \\
\text { current asthma: } \\
\text { OR }=0.90(0.79,1.03) \text {, } \\
1.29(1.17,1.42) \text { and } 1.87 \\
(1.60,2.18) \text { for the BMI } \\
\text { groups < 20.0, 25.0-29.9, } \\
\text { and } \geq 30.0 \text { respectively, } \\
\text { versus the } \\
\text { normal-weight group } \\
\text { (BMI 20.0-24.9). } \\
\text { - No association between } \\
\text { physical activity and } \\
\text { current asthma }\end{array}$ & $\begin{array}{l}\text { Information on diet was } \\
\text { only available once, and } \\
\text { thus total daily energy } \\
\text { intake (assessed using a } \\
\text { validated FFQ) was } \\
\text { considered as a } \\
\text { time-fixed covariate in } \\
\text { the MSMs }\end{array}$ \\
\hline $\begin{array}{l}\text { Garcia-Aymerich J } \\
\text { et al., Am J } \\
\text { Epidemiol } 2014\end{array}$ & $\begin{array}{l}76,470 \text { asthma-free } \\
\text { women from the Nurses' } \\
\text { Health Study who were } \\
\text { followed between } 1988 \\
\text { and } 1998\end{array}$ & $\begin{array}{l}\text { g-formula analysis to } \\
\text { assess the } 10 \text {-year risk of } \\
\text { adult-onset asthma after } \\
\text { hypothetical } \\
\text { interventions on BMI } \\
\text { (i.e., reducing BMI by } 5 \% \\
\text { every } 2 \text { years) } \\
\text { or/and physical activity } \\
\text { (i.e., engaging in at least } \\
2.5 \text { h per week of } \\
\text { moderate-to-vigorous } \\
\text { physical activity) }\end{array}$ & $\begin{array}{l}\text { Adult-onset asthma: } \\
\text { self-reported physician } \\
\text { diagnosis of asthma plus } \\
\text { the use of an asthma } \\
\text { medication in the past } \\
12 \text { months }\end{array}$ & $\begin{array}{l}\text { BMI: calculated using } \\
\text { self-reported height and } \\
\text { weight } \\
\text { Physical activity: total time } \\
\text { spent per week at } \\
\text { moderate-to-vigorous physical } \\
\text { activities (walking at } \geq 3 \\
\text { miles/hour, hiking outdoors, } \\
\text { jogging, running, cycling, } \\
\text { swimming, tennis and } \\
\text { calisthenics/aerobics/aerobic } \\
\text { dance/rowing machine) }\end{array}$ & $\begin{array}{l}\text { Compared with no } \\
\text { intervention, the } \\
\text { population risk ratios } \\
\text { were } 0.96(0.93,0.99) \\
\text { under the BMI } \\
\text { intervention, } 0.96(0.81 \text {, } \\
1.10) \text { under the physical } \\
\text { activity intervention, } \\
\text { and } 0.92(0.78,1.06) \\
\text { under the joint } \\
\text { intervention }\end{array}$ & $\begin{array}{l}\text { Because of a large } \\
\text { proportion of missing } \\
\text { data, diet (assessed the } \\
\text { dietary "prudent } \\
\text { pattern" and "Western } \\
\text { pattern") was considered } \\
\text { as a time-fixed covariate }\end{array}$ \\
\hline
\end{tabular}


2.4.2. The Issue of Time-Dependent Confounding in the Interrelations between Nutritional Factors and Asthma

From a longitudinal perspective, interrelations between nutritional factors and asthma are time-dependent. In addition to the potential role of each nutritional factor at a given time $t$ on asthma at a time $t+1$, asthma at time $t-1$ may have modified nutritional factors at time $t$ (e.g., asthma can lead to a decrease in physical activity), and each nutritional factor at time $t-1$ may have modified another nutritional factor at time $t$ (e.g., overweight/obesity can lead to modifying dietary and/or physical activity behaviors) (Figure 2). Thus, with the issue of the tracking of lifestyle habits and asthma/asthma control across the life course, and given the importance of windows of exposure in the investigation of the role of nutritional factors in asthma, the potential for reverse causation remains an issue, even in longitudinal studies where repeated data are available. Thus, there is an additional issue with time-dependent confounding that needs to be accounted for and, in this situation, standard methods of analysis may provide biased results [114,115].

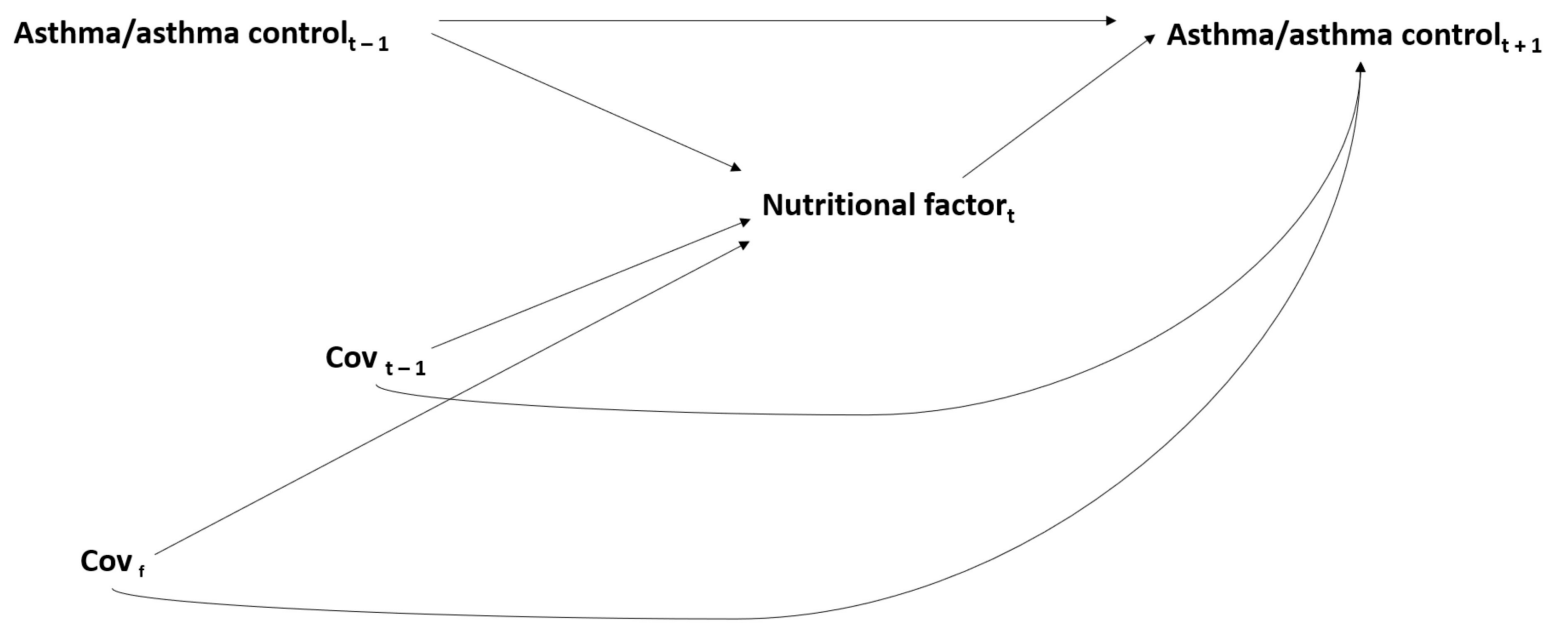

Figure 2. Issue of time-dependent confounding* in the interrelations between nutritional factors and asthma/asthma control. $\operatorname{Cov}_{\mathrm{f}}$ : time-fixed covariates; $\operatorname{Cov}_{\mathrm{t}-1}$ : time-dependent covariates at time $\mathrm{t}-1 ;{ }^{*}$ For simplicity, the interrelations between each nutritional factor are not represented in this figure (see Figure 1).

In longitudinal epidemiological studies, time-dependent confounding can be addressed using novel approaches from the causal inference framework, such as marginal structural models (MSMs) [124]. These models, applicable only with repeated data, have been developed in the frame of the counterfactual approach to causality through inverse probability weighting [125]. This approach allows the estimation of causal effects in observational studies by mimicking a hypothetical randomized experiment via the creation of a pseudo-population in which exposed and non-exposed subjects are exchangeable within levels of the available confounders. The MSM approach has been rarely used in respiratory epidemiology [126-130]. Two studies were conducted to assess the time-dependent associations between physical activity and lung function $[128,130]$ or physical activity and COPD [128]. MSMs have been used in the context of nutritional factors to study the joint effect of physical activity and body composition on functional limitation [131]. To our knowledge, only one study has been conducted in the context of the time-dependent associations between physical activity, BMI and asthma, suggesting an independent causal deleterious effect of overweight and obesity on current asthma, but no independent causal effect of physical activity on current asthma [129] (see Table 1).

The g-formula, which was first described in 1986 by Robins [132], is another counterfactual method that allows adjustment for time-dependent confounding. The g-formula is a generalization of standardization for time-dependent confounders and exposures, 
and can be used to consistently estimate the standardized risk of a health outcome under hypothetical interventions. The g-formula has been widely used to investigate the effect of potential exercise, dietary and/or weight loss interventions in relation with mortality [133], prostate cancer survival [134], periodontitis risk [135] and coronary heart disease (CHD) [136-138]. The g-formula approach has been rarely used in respiratory epidemiology [139-141]. To our knowledge, only one study has used the parametric g-formula in the context of nutritional factors and asthma-in this study, the authors assessed the 10-year risk of adult-onset asthma after hypothetical interventions on BMI and physical activity, and showed a significant reduction in asthma risk associated with weight loss intervention and a non-significant reduction associated with intervention on physical activity level [139] (see Table 1).

Recent developments, generalizing the g-formula to the mediation approach, have further enabled the investigation of interventional direct and indirect effects in the context of available time-dependent exposures and mediators [142]. This approach has already been used to investigate the mediating role of physical inactivity in the association between adult obesity and mid-life physical functioning [143].

\section{The Association between Nutritional Factors and Asthma: An Epiphenomenon of the Complex Interrelations between Genetic, Environmental, Lifestyle and Social Determinants in Asthma}

Aside from the complex interrelations between diet, physical activity, body composition and asthma, nutritional factors may also interact with genetic, environmental, lifestyle and social factors. Few studies have been published regarding this important issue despite the fact that asthma is considered to be caused by a complicated interplay of genetic, environmental, lifestyle and social factors. One way to strengthen causal inference is to demonstrate biologically plausible interactions. A few studies have investigated possible interactions between common antioxidant gene polymorphisms and antioxidant intake or physical activity affecting atopic and respiratory outcomes [144-146]. As obesity is now a well-known risk factor for asthma, trying to understand better how obesity might modify associations between oxidant exposures, such as air pollution, and asthma is particularly relevant [147]. Some studies have suggested that diet may act as an effect modifier and modulate the adverse effect of air pollution on asthma outcomes [148-150]. Investigating the potential interaction between exercise and air pollution, with the issue of whether or not increased exposure to air pollution during exercise outweighs the beneficial effects of physical activity on asthma is also critical in order to guide public health interventions [144,151]. Investigating interactions with smoking is particularly relevant given the complex association between smoking and body weight, and that smokers and non-smokers have different dietary habits and levels of physical activity [152]. Some studies have suggested that diet may act as an effect modifier and attenuate the deleterious effect of smoking on asthma [153], whereas others have suggested that a healthy diet may only be beneficial in never-smokers [64]. Investigating potential interactions between nutritional and social factors is also very relevant given the strong influence of social context on the development of dietary behaviors, lifestyle habits and health outcomes throughout life, and increasing research is focusing on "the exposome" concept in asthma [154,155].

\section{Conclusions}

The investigation of nutritional factors as a whole is highly relevant in the etiology of asthma and its control, both in terms of understanding their underlying mechanisms and in terms of guiding efficient multidimensional public health interventions. To date, few studies on the role of nutritional factors in asthma have properly addressed the methodological challenges posed by the complexity of their interrelations. Therefore, there is a crucial need for further studies investigating these interrelations and for more caution when addressing these conceptual and methodological challenges in the conduct of analysis and the comparison of results. By providing guidance on how to address these challenges, we hope this review will help to identify current research needs and guide future research. 
Author Contributions: Conceptualization, A.B. and R.V.; writing-original draft preparation, A.B., O.D. and R.V.; writing-review and editing, Z.L., W.A.-h., C.A.C.J., B.L. and C.P. All authors have read and agreed to the published version of the manuscript.

Funding: This research was funded by The French National Research Program for Environmental and Occupational Health of Anses (2018/1/055).

Institutional Review Board Statement: Not applicable.

Informed Consent Statement: Not applicable.

Acknowledgments: The authors thank Valérie Siroux for her thoughtful comments on the manuscript.

Conflicts of Interest: The authors declare no conflict of interest.

\section{References}

1. Kyu, H.H.; Abate, D.; Abate, K.H.; Abay, S.M.; Abbafati, C.; Abbasi, N.; Abbastabar, H.; Abd-Allah, F.; Abdela, J.; Abdelalim, A.; et al. Global, regional, and national disability-adjusted life-years (DALYs) for 359 diseases and injuries and healthy life expectancy (HALE) for 195 countries and territories, 1990-2017: A systematic analysis for the Global Burden of Disease Study 2017. Lancet 2018, 392, 1859-1922. [CrossRef]

2. Ferrante, G.; La Grutta, S. The burden of pediatric asthma. Front. Pediatr. 2018, 6, 1-7. [CrossRef] [PubMed]

3. Eder, W.; Ege, M.J.; von Mutius, E. The asthma epidemic. N. Engl. J. Med. 2006, 355, 2226-2235. [CrossRef]

4. Beasley, R.; Semprini, A.; Mitchell, E.A. Risk factors for asthma: Is prevention possible? Lancet 2015, 386, 1075-1085. [CrossRef]

5. Braido, F.; Brusselle, G.; Guastalla, D.; Ingrassia, E.; Nicolini, G.; Price, D.; Roche, N.; Soriano, J.B.; Worth, H. Determinants and impact of suboptimal asthma control in Europe: The INTERNATIONAL CROSS-SECTIONAL AND LONGITUDINAL ASSESSMENT ON ASTHMA CONTROL (LIAISON) study. Respir. Res. 2016, 17, 51. [CrossRef] [PubMed]

6. Global Initiative for Asthma (GINA). Global Strategy for Asthma Management and Prevention 2020. Available online: http: //www.ginasthma.org/ (accessed on 11 March 2021).

7. Health Promotion Glossary. Available online: https:/ /www.who.int/healthpromotion/about/HPG/en/ (accessed on 28 September 2020).

8. von Mutius, E.; Smits, H.H. Primary prevention of asthma: From risk and protective factors to targeted strategies for prevention. Lancet 2020, 396, 854-866. [CrossRef]

9. Varraso, R.; Camargo, C.A. Diet and asthma: Need to account for asthma type and level of prevention. Expert Rev. Respir. Med. 2016, 10, 1147-1150. [CrossRef] [PubMed]

10. Peters, U.; Dixon, A.E.; Forno, E. Obesity and asthma. J. Allergy Clin. Immunol. 2018, 141, 1169-1179. [CrossRef] [PubMed]

11. Novosad, S.; Khan, S.; Wolfe, B.; Khan, A. Role of obesity in asthma control, the obesity-asthma phenotype. J. Allergy 2013, 2013, 538642. [CrossRef]

12. Xie, M.; Wenzel, S.E. A global perspective in asthma: From phenotype to endotype. Chin. Med. J. 2013, 126, 166-174.

13. de Marco, R.; Locatelli, F.; Sunyer, J.; Burney, P. Differences in incidence of reported asthma related to age in men and women. A retrospective analysis of the data of the European Respiratory Health Survey. Am. J. Respir. Crit. Care Med. 2000, 162, 68-74. [CrossRef]

14. Olivenstein, R.; Hamid, Q. Asthma in the elderly ... Their time is right now. Clin. Exp. Allergy 2011, 41, 457-458. [CrossRef]

15. Orie, N.; Sluiter, H.; De Vries, K.; Tammeling, G.; Witkop, J. The host factor in bronchitis. In Bronchitis; Orie, N., Sluiter, H., Eds.; Royal Van Gorcum: Assen, The Netherlands, 1961; pp. 43-59.

16. Taylor, D.R.; Cowan, J.O.; Greene, J.M.; Willan, A.R.; Sears, M.R. Asthma in remission: Can relapse in early adulthood be predicted at 18 years of age? Chest 2005, 127, 845-850. [CrossRef] [PubMed]

17. Martinez, F.D.; Wright, A.L.; Taussig, L.M.; Holberg, C.J.; Halonen, M.; Morgan, W.J. Asthma and wheezing in the first six years of life. N. Engl. J. Med. 1995, 332, 133-138. [CrossRef] [PubMed]

18. Ferris, B.G. Epidemiology Standardization Project (American Thoracic Society). Am. Rev. Respir. Dis. 1978, 118, 1-120. [PubMed]

19. Brille, D.; Casula, D.; van der Lende, R.; Smidt, U.; Minette, A. Commentaires relatifs au questionnaire pour l'étude de la bronchite chronique et de l'emphysème pulmonaire. In British Medical Research Council/Communauté Européenne du Charbon et de l'Acier; Collection D’hygiène et de Médecine et du Travail, n¹4; CEE-CECA: Luxembourg, 1971.

20. Sunyer, J.; Pekkanen, J.; Garcia-Esteban, R.; Svanes, C.; Künzli, N.; Janson, C.; de Marco, R.; Antó, J.M.; Burney, P. Asthma score: Predictive ability and risk factors. Allergy 2007, 62, 142-148. [CrossRef] [PubMed]

21. Pekkanen, J.; Sunyer, J.; Anto, J.M.; Burney, P. Operational definitions of asthma in studies on its aetiology. Eur. Respir. J. 2005, 26, 28-35. [CrossRef] [PubMed]

22. Liu, A.H.; Zeiger, R.; Sorkness, C.; Mahr, T.; Ostrom, N.; Burgess, S.; Rosenzweig, J.C.; Manjunath, R. Development and cross-sectional validation of the Childhood Asthma Control Test. J. Allergy Clin. Immunol. 2007, 119, 817-825. [CrossRef]

23. Cloutier, M.M.; Schatz, M.; Castro, M.; Clark, N.; Kelly, H.W.; Mangione-Smith, R.; Sheller, J.; Sorkness, C.; Stoloff, S.; Gergen, P. Asthma outcomes: Composite scores of asthma control. J. Allergy Clin. Immunol. 2012, 129, S24-S33. [CrossRef]

24. Hu, F.B. Dietary pattern analysis: A new direction in nutritional epidemiology. Curr. Opin. Lipidol. 2002, 13, 3-9. [CrossRef] 
25. Trichopoulou, A.; Kouris-Blazos, A.; Wahlqvist, M.L.; Gnardellis, C.; Lagiou, P.; Polychronopoulos, E.; Vassilakou, T.; Lipworth, L.; Trichopoulos, D. Diet and overall survival in elderly people. BMJ 1995, 311, 1457-1460. [CrossRef] [PubMed]

26. Chiuve, S.E.; Fung, T.T.; Rimm, E.B.; Hu, F.B.; Mccullough, M.L.; Wang, M.; Stampfer, M.J.; Willett, W.C. Alternative Dietary Indices Both Strongly Predict Risk of Chronic Disease. J. Nutr. 2012, 142, 1009-1018. [CrossRef]

27. Pellegrini, N.; Serafini, M.; Colombi, B.; Del Rio, D.; Salvatore, S.; Bianchi, M.; Brighenti, F. Total antioxidant capacity of plant foods, beverages and oils consumed in Italy assessed by three different in vitro assays. J. Nutr. 2003, 133, 2812-2819. [CrossRef] [PubMed]

28. Cavicchia, P.P.; Steck, S.E.; Hurley, T.G.; Hussey, J.R.; Ma, Y.; Ockene, I.S.; Hebert, J.R. A New Dietary Inflammatory Index Predicts Interval Changes in Serum High-Sensitivity C-Reactive Protein. J. Nutr. 2009, 2365-2372. [CrossRef] [PubMed]

29. Willett, W.C. 24-hour recall and diet record methods. In Nutritional Epidemiology; Oxford University Press: New York, NY, USA, 2012; pp. 49-69.

30. Willett, W.C. Reproducibility and validity of food-frequency questionnaires. In Nutritional Epidemiology; Oxford University Press: New York, NY, USA, 2012; pp. 96-141.

31. Craig, C.L.; Marshall, A.L.; Sjöström, M.; Bauman, A.E.; Booth, M.L.; Ainsworth, B.E.; Pratt, M.; Ekelund, U.; Yngve, A.; Sallis, J.F.; et al. International physical activity questionnaire: 12-Country reliability and validity. Med. Sci. Sports Exerc. 2003, 35, 1381-1395. [CrossRef]

32. IPAQ Scoring Protocol. Available online: https://sites.google.com/site/theipaq/scoring-protocol (accessed on 11 March 2021).

33. Migueles, J.H.; Cadenas-Sanchez, C.; Ekelund, U.; Delisle Nyström, C.; Mora-Gonzalez, J.; Löf, M.; Labayen, I.; Ruiz, J.R.; Ortega, F.B. Accelerometer Data Collection and Processing Criteria to Assess Physical Activity and Other Outcomes: A Systematic Review and Practical Considerations. Sport. Med. 2017, 47, 1821-1845. [CrossRef] [PubMed]

34. Helmerhorst, H.J.F.; Brage, S.; Warren, J.; Besson, H.; Ekelund, U. A systematic review of reliability and objective criterion-related validity of physical activity questionnaires. Int. J. Behav. Nutr. Phys. Act. 2012, 9, 103. [CrossRef]

35. World Health Organisation (WHO). Obesity and Overweight, Fact Sheet No 311 (Updated August 2014). Available online: http:/ / www.who.int/mediacentre/factsheets/fs311/en/ (accessed on 11 March 2021).

36. National Center for Chronic Disease Prevention and Health Promotion, Centers for Disease Control and Prevention. BMI: Body mass index. In Atlanta, GA: Centers for Disease Control and Prevention; 2002. Available online: http://www.cdc.gov/healthyweight/ assessing/bmi/index.html (accessed on 11 March 2021).

37. Palta, M.; Prineas, R.J.; Berman, R.; Hannan, P. Comparison of self-reported and measured height and weight. Am. J. Epidemiol. 1982, 115, 223-230. [CrossRef]

38. Willett, W.C. Anthropometric measures and body composition. In Nutritional Epidemiology; Oxford University Press: New York, NY, USA, 2012; pp. 213-240.

39. Peralta, G.P.; Fuertes, E.; Granell, R.; Mahmoud, O.; Roda, C.; Serra, I.; Jarvis, D.; Henderson, J.; Garcia-Aymerich, J. Childhood body composition trajectories and adolescent lung function findings from the ALSPAC study. Am. J. Respir. Crit. Care Med. 2019, 200, 75-83. [CrossRef]

40. Brozek, J.; Grande, F.; Anderson, J.T.; Keys, A. Densitometric analysis of body composition: Revision of some quantitative assumptions. Ann. N.Y. Acad. Sci. 1963, 110, 113-140. [CrossRef]

41. Roubenoff, R.; Kehayias, J.J.; Dawson-Hughes, B.; Heymsfield, S.B. Use of dual-energy x-ray absorptiometry in body-composition studies: Not yet a "gold standard". Am. J. Clin. Nutr. 1993, 58, 589-591. [CrossRef]

42. Baumgartner, R.N. Electrical impedance and total body electrical conductivity. In Human Body Composition; Heymsfield, S.B., Wang, Z.M., Baumgartner, R.N., Eds.; Human Kinetics: Champaign, IL, USA, 1996; pp. 79-108.

43. Willett, K.; Jiang, R.; Lenart, E.; Spiegelman, D.; Willett, W. Comparison of bioelectrical impedance and BMI in predicting obesity-related medical conditions. Obesity 2006, 14, 480-490. [CrossRef] [PubMed]

44. Sørensen, T.I.; Stunkard, A.J. Does obesity run in families because of genes? An adoption study using silhouettes as a measure of obesity. Acta Psychiatr. Scand. Suppl. 1993, 370, 67-72. [CrossRef]

45. Garcia-Larsen, V.; Ierodiakonou, D.; Jarrold, K.; Cunha, S.; Chivinge, J.; Robinson, Z.; Geoghegan, N.; Ruparelia, A.; Devani, P.; Trivella, M.; et al. Diet during pregnancy and infancy and risk of allergic or autoimmune disease: A systematic review and meta-analysis. PLoS Med. 2018, 15, e1002507. [CrossRef]

46. Beckhaus, A.A.; Garcia-Marcos, L.; Forno, E.; Pacheco-Gonzalez, R.M.; Celedón, J.C.; Castro-Rodriguez, J.A. Maternal nutrition during pregnancy and risk of asthma, wheeze, and atopic diseases during childhood: A systematic review and meta-analysis. Allergy 2015, 70, 1588-1604. [CrossRef] [PubMed]

47. Venter, C.; Agostoni, C.; Arshad, S.H.; Ben-Abdallah, M.; Du Toit, G.; Fleischer, D.M.; Greenhawt, M.; Glueck, D.H.; Groetch, M.; Lunjani, N.; et al. Dietary factors during pregnancy and atopic outcomes in childhood: A systematic review from the European Academy of Allergy and Clinical Immunology. Pediatr. Allergy Immunol. 2020. [CrossRef] [PubMed]

48. Castro-Rodriguez, J.A.; Garcia-Marcos, L. What Are the Effects of a Mediterranean Diet on Allergies and Asthma in Children? Front. Pediatr. 2017, 5, 72. [CrossRef]

49. Hanson, C.; Rifas-Shiman, S.L.; Shivappa, N.; Wirth, M.D.; Hebert, J.R.; Gold, D.; Camargo, C.A.; Sen, S.; Sordillo, J.E.; Oken, E.; et al. Associations of Prenatal Dietary Inflammatory Potential with Childhood Respiratory Outcomes in Project Viva. J. Allergy Clin. Immunol. Pract. 2020, 8, 945-952e4. [CrossRef] [PubMed] 
50. Bisgaard, H.; Stokholm, J.; Chawes, B.L.; Vissing, N.H.; Bjarnadóttir, E.; Schoos, A.-M.M.; Wolsk, H.M.; Pedersen, T.M.; Vinding, R.K.; Thorsteinsdóttir, S.; et al. Fish Oil-Derived Fatty Acids in Pregnancy and Wheeze and Asthma in Offspring. N. Engl. J. Med. 2016, 375, 2530-2539. [CrossRef]

51. Best, K.P.; Sullivan, T.; Palmer, D.; Gold, M.; Kennedy, D.J.; Martin, J.; Makrides, M. Prenatal fish oil supplementation and allergy: 6-Year follow-up of a randomized controlled trial. Pediatrics 2016, 137, e20154443. [CrossRef] [PubMed]

52. Bédard, A.; Northstone, K.; John Henderson, A.; Shaheen, S.O. Mediterranean diet during pregnancy and childhood respiratory and atopic outcomes: Birth cohort study. Eur. Respir. J. 2020, 55, 1901215. [CrossRef] [PubMed]

53. Shaheen, S.O.; Gissler, M.; Gissler, M.; Devereux, G.; Erkkola, M.; Kinnunen, T.I.; Mcardle, H.; Sheikh, A.; Hemminki, E.; Nwaru, B.I.; et al. Maternal iron supplementation in pregnancy and asthma in the offspring: Follow-up of a randomised trial in Finland. Eur. Respir. J. 2020, 55, 1902335. [CrossRef]

54. Bédard, A.; Northstone, K.; Henderson, A.J.; Shaheen, S.O. Maternal intake of sugar during pregnancy and childhood respiratory and atopic outcomes. Eur. Respir. J. 2017, 50, 1700073. [CrossRef]

55. Wright, L.S.; Rifas-Shiman, S.L.; Oken, E.; Litonjua, A.A.; Gold, D.R. Prenatal and early life fructose, fructose-containing beverages, and midchildhood asthma. Ann. Am. Thorac. Soc. 2018, 15, 217-224. [CrossRef]

56. Chen, L.W.; Lyons, B.; Navarro, P.; Shivappa, N.; Mehegan, J.; Murrin, C.M.; Hébert, J.R.; Kelleher, C.C.; Phillips, C.M. Maternal dietary inflammatory potential and quality are associated with offspring asthma risk over 10-year follow-up: The Lifeways Cross-Generation Cohort Study. Am. J. Clin. Nutr. 2020, 111, 440-447. [CrossRef]

57. Leynaert, B.; Le Moual, N.; Neukirch, C.; Siroux, V.; Varraso, R. Environmental risk factors for asthma developement. La Presse Médicale 2019, 48, 262-273. [CrossRef]

58. Papamichael, M.M.; Shrestha, S.K.; Itsiopoulos, C.; Erbas, B. The role of fish intake on asthma in children: A meta-analysis of observational studies. Pediatr. Allergy Immunol. 2018, 29, 350-360. [CrossRef] [PubMed]

59. Tromp, I.I.M.; Kiefte-de Jong, J.C.; de Vries, J.H.; Jaddoe, V.W.V.; Raat, H.; Hofman, A.; de Jongste, J.C.; Moll, H.A. Dietary patterns and respiratory symptoms in pre-school children: The Generation R Study. Eur. Respir. J. 2012, 40, 681-689. [CrossRef]

60. Guilleminault, L.; Williams, E.J.; Scott, H.A.; Berthon, B.S.; Jensen, M.; Wood, L.G. Diet and asthma: Is it time to adapt our message? Nutrients 2017, 9, 1227. [CrossRef] [PubMed]

61. Andrianasolo, R.M.; Hercberg, S.; Kesse-Guyot, E.; Druesne-Pecollo, N.; Touvier, M.; Galan, P.; Varraso, R. Association between dietary fibre intake and asthma (symptoms and control): Results from the French national e-cohort NutriNet-Santé. Br. J. Nutr. 2019, 122, 1040-1051. [CrossRef] [PubMed]

62. Li, Z.; Rava, M.; Bédard, A.; Dumas, O.; Garcia-Aymerich, J.; Leynaert, B.; Pison, C.; Le Moual, N.; Romieu, I.; Siroux, V.; et al. Cured meat intake is associated with worsening asthma symptoms. Thorax 2017, 72, 206-212. [CrossRef]

63. Andrianasolo, R.M.; Hercberg, S.; Touvier, M.; Druesne-Pecollo, N.; Adjibade, M.; Kesse-Guyot, E.; Galan, P.; Varraso, R. Association between processed meat intake and asthma symptoms in the French NutriNet-Santé cohort. Eur. J. Nutr. 2020, 59, 1553-1562. [CrossRef] [PubMed]

64. Li, Z.; Kesse-Guyot, E.; Dumas, O.; Garcia-Aymerich, J.; Leynaert, B.; Pison, C.; Le Moual, N.; Romieu, I.; Siroux, V.; Camargo, C.A.; et al. Longitudinal study of diet quality and change in asthma symptoms in adults, according to smoking status. Br. J. Nutr. 2017, 117, 562-571. [CrossRef] [PubMed]

65. Andrianasolo, R.M.; Kesse-Guyot, E.; Adjibade, M.; Hercberg, S.; Galan, P.; Varraso, R. Associations between dietary scores with asthma symptoms and asthma control in adults. Eur. Respir. J. 2018, 52, 1702572. [CrossRef]

66. Varraso, R.; Jiang, R.; Barr, R.G.; Willett, W.C.; Camargo, C. a Prospective study of cured meats consumption and risk of chronic obstructive pulmonary disease in men. Am. J. Epidemiol. 2007, 166, 1438-1445. [CrossRef]

67. Jiang, R.; Camargo, C.A.; Varraso, R.; Paik, D.C.; Willett, W.C.; Barr, R.G. Consumption of cured meats and prospective risk of chronic obstructive pulmonary disease in women. Am. J. Clin. Nutr. 2008, 87, 1002-1008. [CrossRef]

68. Varraso, R.; Chiuve, S.E.; Fung, T.T.; Barr, R.G.; Hu, F.B.; Willett, W.C.; Camargo, C.A. Alternate Healthy Eating Index 2010 and risk of chronic obstructive pulmonary disease among US women and men: Prospective study. BMJ 2015, 350, 1-11. [CrossRef]

69. DeChristopher, L.R.; Tucker, K.L. Excess free fructose, high-fructose corn syrup and adult asthma: The Framingham Offspring Cohort. Br. J. Nutr. 2018, 119, 1157-1167. [CrossRef]

70. Cassim, R.; Russell, M.A.; Lodge, C.J.; Lowe, A.J.; Koplin, J.J.; Dharmage, S.C. The role of circulating 25 hydroxyvitamin D in asthma: A systematic review. Allergy Eur. J. Allergy Clin. Immunol. 2015, 70, 339-354. [CrossRef] [PubMed]

71. Varraso, R.; Kauffmann, F.; Leynaert, B.; Le Moual, N.; Boutron-Ruault, M.C.; Clavel-Chapelon, F.; Romieu, I. Dietary patterns and asthma in the E3N study. Eur. Respir. J. 2009, 33, 33-41. [CrossRef]

72. el Bilbeisi, A.H.H.; Albelbeisi, A.; Hosseini, S.; Djafarian, K. Dietary Pattern and Their Association With Level of Asthma Control Among Patients with Asthma at Al-Shifa Medical Complex in Gaza Strip, Palestine. Nutr. Metab. Insights 2019, 12. [CrossRef] [PubMed]

73. Barros, R.; Moreira, A.; Fonseca, J.; de Oliveira, J.F.; Delgado, L.; Barros, R.; Haahtela, T.; Lopes, C.; Castel-Branco, M.G.; Moreira, P. Adherence to the Mediterranean diet and fresh fruit intake are associated with improved asthma control. Allergy 2008, 63, 917-923. [CrossRef]

74. Sexton, P.; Black, P.; Metcalf, P.; Wall, C.R.; Ley, S.; Wu, L.; Sommerville, F.; Brodie, S.; Kolbe, J. Influence of mediterranean diet on asthma symptoms, lung function, and systemic inflammation: A randomized controlled trial. J. Asthma 2013, 50, 75-81. [CrossRef] 
75. Ma, J.; Strub, P.; Lv, N.; Xiao, L.; Camargo, C.A.; Buist, A.S.; Lavori, P.W.; Wilson, S.R.; Nadeau, K.C.; Rosas, L.G. Pilot randomised trial of a healthy eating behavioural intervention in uncontrolled asthma. Eur. Respir. J. 2016, 47, 122-132. [CrossRef]

76. Eijkemans, M.; Mommers, M.; Draaisma, J.M.T.; Thijs, C.; Prins, M.H. Physical activity and asthma: A systematic review and meta-analysis. PLoS ONE 2012, 7, e50775. [CrossRef] [PubMed]

77. Lochte, L.; Nielsen, K.G.; Petersen, P.E.; Platts-Mills, T.A.E. Childhood asthma and physical activity: A systematic review with meta-analysis and graphic appraisal tool for epidemiology assessment. BMC Pediatr. 2016, 16, 1-13. [CrossRef] [PubMed]

78. Freeman, A.T.; Staples, K.J.; Wilkinson, T.M.A. Defining a role for exercise training in the management of asthma. Eur. Respir. Rev. 2020, 29, 190106. [CrossRef] [PubMed]

79. Freitas, P.D.; Ferreira, P.G.; Silva, A.G.; Stelmach, R.; Carvalho-Pinto, R.M.; Fernandes, F.L.A.; Mancini, M.C.; Sato, M.N.; Martins, M.A.; Carvalho, C.R.F. The role of exercise in a weight-loss program on clinical control in obese adults with Asthma: A randomized controlled trial. Am. J. Respir. Crit. Care Med. 2017, 195, 32-42. [CrossRef]

80. Türk, Y.; Theel, W.; Van Huisstede, A.; Van De Geijn, G.J.M.; Birnie, E.; Hiemstra, P.S.; Sont, J.K.; Taube, C.; Braunstahl, G.J. Shortterm and long-term effect of a high-intensity pulmonary rehabilitation programme in obese patients with asthma: A randomised controlled trial. Eur. Respir. J. 2020, 56. [CrossRef]

81. Camargo, C.A.; Weiss, S.T.; Zhang, S.; Willett, W.C.; Speizer, F.E. Prospective study of body mass index, weight change, and risk of adult-onset asthma in women. Arch. Intern. Med. 1999, 159, 2582-2588. [CrossRef]

82. Burgess, J.A.; Walters, E.H.; Byrnes, G.B.; Giles, G.G.; Jenkins, M.A.; Abramson, M.J.; Hopper, J.L.; Dharmage, S.C. Childhood adiposity predicts adult-onset current asthma in females: A 25-yr prospective study. Eur. Respir. J. 2007, 29, 668-675. [CrossRef]

83. Scholtens, S.; Wijga, A.H.; Seidell, J.C.; Brunekreef, B.; de Jongste, J.C.; Gehring, U.; Postma, D.S.; Kerkhof, M.; Smit, H.A. Overweight and changes in weight status during childhood in relation to asthma symptoms at 8 years of age. J. Allergy Clin. Immunol. 2009, 123, 1312-1318.e2. [CrossRef]

84. Romieu, I.; Avenel, V.; Leynaert, B.; Kauffmann, F.; Clavel-Chapelon, F. Body mass index, change in body silhouette, and risk of asthma in the E3N cohort study. Am. J. Epidemiol. 2003, 158, 165-174. [CrossRef] [PubMed]

85. Dumas, O.; Varraso, R.; Gillman, M.W.; Field, A.E.; Camargo, C.A. Longitudinal study of maternal body mass index, gestational weight gain, and offspring asthma. Allergy 2016. [CrossRef]

86. Liu, S.; Zhou, B.; Wang, Y.; Wang, K.; Zhang, Z.; Niu, W. Pre-pregnancy maternal weight and gestational weight gain increase the risk for childhood asthma and wheeze: An updated meta-analysis. Front. Pediatr. 2020, 8. [CrossRef] [PubMed]

87. Beuther, D.A.; Sutherland, E.R. Overweight, obesity, and incident asthma: A meta-analysis of prospective epidemiologic studies. Am. J. Respir. Crit. Care Med. 2007, 175, 661-666. [CrossRef] [PubMed]

88. Chen, Z.; Salam, M.T.; Alderete, T.L.; Habre, R.; Bastain, T.M.; Berhane, K.; Gilliland, F.D. Effects of childhood asthma on the development of obesity among school-aged children. Am. J. Respir. Crit. Care Med. 2017, 195, 1181-1188. [CrossRef]

89. Contreras, Z.A.; Chen, Z.; Roumeliotaki, T.; Annesi-Maesano, I.; Baïz, N.; von Berg, A.; Bergström, A.; Crozier, S.; Duijts, L.; Ekström, S.; et al. Does early onset asthma increase childhood obesity risk? A pooled analysis of 16 European cohorts. Eur. Respir. J. 2018, 52. [CrossRef]

90. Juel, C.T.B.; Ali, Z.; Nilas, L.; Ulrik, C.S. Asthma and obesity: Does weight loss improve asthma control? A systematic review. J. Asthma Allergy 2012, 21-26. [CrossRef]

91. Marchesi, J.R.; Adams, D.H.; Fava, F.; Hermes, G.D.A.; Hirsch, G.M.; Hold, G.; Quraishi, M.N.; Kinross, J.; Smidt, H.; Tuohy, K.M.; et al. The gut microbiota and host health: A new clinical frontier. Gut 2016, 65, 330-339. [CrossRef]

92. Trompette, A.; Gollwitzer, E.S.; Yadava, K.; Sichelstiel, A.K.; Sprenger, N.; Ngom-bru, C.; Blanchard, C.; Junt, T.; Nicod, L.P.; Harris, N.L.; et al. Gut microbiota metabolism of dietary fiber influences allergic airway disease and hematopoiesis. Nat. Med. 2014, 20, 159-168. [CrossRef]

93. Denou, E.; Marcinko, K.; Surette, M.G.; Steinberg, G.R.; Schertzer, J.D. High-intensity exercise training increases the diversity and metabolic capacity of the mouse distal gut microbiota during diet-induced obesity. Am. J. Physiol. Endocrinol. Metab. 2016, 310, 982-993. [CrossRef]

94. Enaud, R.; Prevel, R.; Ciarlo, E.; Beaufils, F. The Gut-Lung Axis in Health and Respiratory Diseases: A Place for Inter-Organ and Inter-Kingdom Crosstalks. Front. Cell. Infect. Microbiol. 2020, 10, 1-11. [CrossRef]

95. Alemao, C.A.; Budden, K.F.; Gomez, H.M.; Rehman, S.F.; Marshall, J.E.; Shukla, S.D.; Donovan, C.; Forster, S.C.; Yang, I.A.; Keely, S.; et al. Impact of diet and the bacterial microbiome on the mucous barrier and immune disorders. Allergy Eur. J. Allergy Clin. Immunol. 2020, 1-21. [CrossRef] [PubMed]

96. Alsharairi, N.A. The infant gut microbiota and risk of asthma: The effect of maternal nutrition during pregnancy and lactation. Microorganisms 2020, 8, 1119. [CrossRef] [PubMed]

97. Boulet, L.-P. Asthma and obesity. Clin. Exp. Allergy 2013, 43, 8-21. [CrossRef]

98. Chapman, D.G.; Salome, C.M. Lifestyles of the fat and lazy. Clin. Exp. Allergy 2013, 43, 2-4. [CrossRef]

99. Lucas, S.R.; Platts-Mills, T.A.E. Physical activity and exercise in asthma: Relevance to etiology and treatment. J. Allergy Clin. Immunol. 2005, 115, 928-934. [CrossRef] [PubMed]

100. Sharma, S.; Litonjua, A. Asthma, allergy, and responses to methyl donor supplements and nutrients. J. Allergy Clin. Immunol. 2014, 133, 1246-1254. [CrossRef]

101. Camargo, C.A.J. Vitamin D, acute respiratory infection, and asthma/chronic obstructive pulmonary disease. In Vitamin D, 4 th ed.; Feldman, D., Pike, J.W., Bouillon, R., Eds.; Elsevier Academic Press: Cambridge, MA, USA, 2018; pp. $1096-1120$. 
102. Nyenhuis, S.M.; Dixon, A.E.; Ma, J. Impact of Lifestyle Interventions Targeting Healthy Diet, Physical Activity, and Weight Loss on Asthma in Adults: What Is the Evidence? J. Allergy Clin. Immunol. Pract. 2018, 6, 751-763. [CrossRef] [PubMed]

103. Ma, J.; Strub, P.; Xiao, L.; Lavori, P.W.; Camargo, C.A.; Wilson, S.R.; Gardner, C.D.; Buist, A.S.; Haskell, W.L.; Lv, N. Behavioral weight loss and physical activity intervention in obese adults with asthma: A randomized trial. Ann. Am. Thorac. Soc. 2015, 12, 1-11. [CrossRef]

104. Toennesen, L.L.; Meteran, H.; Hostrup, M.; Wium Geiker, N.R.; Jensen, C.B.; Porsbjerg, C.; Astrup, A.; Bangsbo, J.; Parker, D.; Backer, V. Effects of Exercise and Diet in Nonobese Asthma Patients-A Randomized Controlled Trial. J. Allergy Clin. Immunol. Pract. 2018, 6, 803-811. [CrossRef]

105. Garcia-Marcos, L.; Canflanca, I.M.; Garrido, J.B.; Varela, A.L.-S.; Garcia-Hernandez, G.; Guillen Grima, F.; Gonzalez-Diaz, C.; Carvajal-Urueña, I.; Arnedo-Pena, A.; Busquets-Monge, R.M.; et al. Relationship of asthma and rhinoconjunctivitis with obesity, exercise and Mediterranean diet in Spanish schoolchildren. Thorax 2007, 62, 503-508. [CrossRef] [PubMed]

106. Romieu, I.; Mannino, D.M.; Redd, S.C.; McGeehin, M.A. Dietary intake, physical activity, body mass index, and childhood asthma in the Third National Health and Nutrition Survey (NHANES III). Pediatr. Pulmonol. 2004, 38, 31-42. [CrossRef] [PubMed]

107. Corbo, G.M.; Forastiere, F.; De Sario, M.; Brunetti, L.; Bonci, E.; Bugiani, M.; Chellini, E.; La Grutta, S.; Migliore, E.; Pistelli, R.; et al. Wheeze and asthma in children: Associations with body mass index, sports, television viewing, and diet. Epidemiology 2008, 19, 747-755. [CrossRef]

108. Mitchell, E.A.; Beasley, R.; Björkstén, B.; Crane, J.; García-Marcos, L.; Keil, U. The association between BMI, vigorous physical activity and television viewing and the risk of symptoms of asthma, rhinoconjunctivitis and eczema in children and adolescents: ISAAC Phase Three. Clin. Exp. Allergy 2013, 43, 73-84. [CrossRef]

109. Lawson, J.A.; Rennie, D.C.; Dosman, J.A.; Cammer, A.L.; Senthilselvan, A. Obesity, diet, and activity in relation to asthma and wheeze among rural dwelling children and adolescents. J. Obes. 2013, 2013, 315096. [CrossRef]

110. Beckett, W.S.; Jacobs, D.R.; Yu, X.; Iribarren, C.; Williams, O.D. Asthma is associated with weight gain in females but not males, independent of physical activity. Am. J. Respir. Crit. Care Med. 2001, 164, 2045-2050. [CrossRef]

111. Kilpeläinen, M.; Terho, E.O.; Helenius, H.; Koskenvuo, M. Body mass index and physical activity in relation to asthma and atopic diseases in young adults. Respir. Med. 2006, 100, 1518-1525. [CrossRef]

112. Chen, Y.-C.; Tu, Y.-K.; Huang, K.-C.; Chen, P.-C.; Chu, D.-C.; Lee, Y.L. Pathway From Central Obesity to Childhood Asthma: Physical Fitness and Sedentary Time Are Leading Factors. Am. J. Respir. Crit. Care Med. 2014, 189, 1194-1203. [CrossRef] [PubMed]

113. Morales, E.; Strachan, D.; Asher, I.; Ellwood, P.; Pearce, N.; Garcia-Marcos, L. Combined impact of healthy lifestyle factors on risk of asthma, rhinoconjunctivitis and eczema in school children: ISAAC phase III. Thorax 2019, 74, 531-538. [CrossRef] [PubMed]

114. Shrier, I.; Platt, R.W. Reducing bias through directed acyclic graphs. BMC Med. Res. Methodol. 2008, 8, 70. [CrossRef]

115. Schisterman, E.F.; Cole, S.R.; Platt, R.W. Overadjustment bias and unnecessary adjustment in epidemiologic studies. Epidemiology 2009, 20, 488-495. [CrossRef]

116. Lange, T.; Vansteelandt, S.; Bekaert, M. A Simple Unified Approach for Estimating Natural Direct and Indirect Effects. Am. J. Epidemiol. 2012, 176, 190-195. [CrossRef]

117. Valeri, L.; VanderWeele, T.J. Mediation analysis allowing for exposure-mediator interactions and causal interpretation: Theoretical assumptions and implementation with SAS and SPSS macros. Psychol. Methods 2013, 18, 137-150. [CrossRef]

118. Audureau, E.; Pouchot, J.; Coste, J. Gender-related differential effects of obesity on health-related quality of life via obesity-related comorbidities. Circ. Cardiovasc. Qual. Outcomes 2016, 9, 246-256. [CrossRef]

119. He, H.; Wang, B.; Zhou, M.; Cao, L.; Qiu, W.; Mu, G.; Chen, A.; Yang, S.; Chen, W. Systemic inflammation mediates the associations between abdominal obesity indices and lung function decline in a chinese general population. Diabetes Metab. Syndr. Obes. Targets Ther. 2020, 13, 141-150. [CrossRef] [PubMed]

120. Fuertes, E.; Carsin, A.E.; Garcia-Larsen, V.; Guerra, S.; Pin, I.; Leynaert, B.; Accordini, S.; Martinez-Moratalla, J.; Antó, J.M.; Urrutia, I.; et al. The role of C-reactive protein levels on the association of physical activity with lung function in adults. PLoS ONE 2019, 14, e0222578. [CrossRef] [PubMed]

121. Van Nimwegen, F.A.; Penders, J.; Stobberingh, E.E.; Postma, D.S.; Koppelman, G.H.; Kerkhof, M.; Reijmerink, N.E.; Dompeling, E.; Van Den Brandt, P.A.; Ferreira, I.; et al. Mode and place of delivery, gastrointestinal microbiota, and their influence on asthma and atopy. J. Allergy Clin. Immunol. 2011, 128, 948-955e3. [CrossRef]

122. Campbell, B.; Simpson, J.A.; Bui, D.S.; Lodge, C.J.; Lowe, A.J.; Matheson, M.C.; Bowatte, G.; Burgess, J.A.; Hamilton, G.S.; Leynaert, B.; et al. Early menarche is associated with lower adult lung function: A longitudinal cohort study from the first to sixth decade of life. Respirology 2020, 25, 289-297. [CrossRef]

123. Assmann, K.E.; Ruhunuhewa, I.; Adjibade, M.; Li, Z.; Varraso, R.; Hercberg, S.; Galan, P.; Kesse-Guyot, E. The mediating role of overweight and obesity in the prospective association between overall dietary quality and healthy aging. Nutrients 2018, 10, 515. [CrossRef]

124. Robins, J.M.; Hernán, M.A.; Brumback, B. Marginal structural models and causal inference in epidemiology. Epidemiology 2000, 11, 550-560. [CrossRef]

125. Hernan, M.A. A definition of causal effect for epidemiological research. J. Epidemiol. Community Heal. 2004, 58, 265-271. [CrossRef] 
126. Sparks, J.A.; Lin, T.C.; Camargo, C.A.; Barbhaiya, M.; Tedeschi, S.K.; Costenbader, K.H.; Raby, B.A.; Choi, H.K.; Karlson, E.W. Rheumatoid arthritis and risk of chronic obstructive pulmonary disease or asthma among women: A marginal structural model analysis in the Nurses' Health Study. Semin. Arthritis Rheum. 2018, 47, 639-648. [CrossRef]

127. Dumas, O.; Le Moual, N.; Siroux, V.; Heederik, D.; Garcia-Aymerich, J.; Varraso, R.; Kauffmann, F.; Basagaña, X. Work related asthma. A causal analysis controlling the healthy worker effect. Occup. Environ. Med. 2013, 70, 603-610. [CrossRef]

128. Garcia-Aymerich, J.; Lange, P.; Serra, I.; Schnohr, P.; Antó, J.M. Time-dependent confounding in the study of the effects of regular physical activity in chronic obstructive pulmonary disease: An application of the marginal structural model. Ann. Epidemiol. 2008, 18, 775-783. [CrossRef] [PubMed]

129. Bédard, A.; Serra, I.; Dumas, O.; Basaganã, X.; Clavel-Chapelon, F.; Le Moual, N.; Sanchez, M.; Siroux, V.; Varraso, R.; Garcia-Aymerich, J. Time-Dependent Associations between Body Composition, Physical Activity, and Current Asthma in Women: A Marginal Structural Modeling Analysis. Am. J. Epidemiol. 2017, 186, 21-28. [CrossRef] [PubMed]

130. Bédard, A.; Carsin, A.E.; Fuertes, E.; Accordini, S.; Dharmage, S.C.; Garcia-Larsen, V.; Heinrich, J.; Janson, C.; Johannessen, A.; Leynaert, B.; et al. Physical activity and lung function-Cause or consequence? PLoS ONE 2020, 15, e0237769. [CrossRef] [PubMed]

131. Tager, I.B.; Haight, T.; Sternfeld, B.; Yu, Z.; van Der Laan, M. Effects of Physical Activity and Body Composition on Functional Limitation in the Elderly. Epidemiology 2004, 15, 479-493. [CrossRef] [PubMed]

132. Robins, J. A new approach to causal inference in mortality studies with a sustained exposure period-Application to control of the healthy worker survivor effect. Math Mod. 1986, 7, 1393-1512. [CrossRef]

133. Williamson, E.J.; Polak, J.; Simpson, J.A.; Giles, G.G.; English, D.R.; Hodge, A.; Gurrin, L.; Forbes, A.B. Sustained adherence to a Mediterranean diet and physical activity on all-cause mortality in the Melbourne Collaborative Cohort Study: Application of the g-formula. BMC Public Health 2019, 19, 1733. [CrossRef] [PubMed]

134. Dickerman, B.A.; Giovannucci, E.; Pernar, C.H.; Mucci, L.A.; Hernán, M.A. Guideline-based physical activity and survival among US men with nonmetastatic prostate cancer. Am. J. Epidemiol. 2019, 188, 579-586. [CrossRef]

135. Nascimento, G.G.; Peres, M.A.; Mittinty, M.N.; Peres, K.G.; Do, L.G.; Horta, B.L.; Gigante, D.P.; Corrêa, M.B.; Demarco, F.F. Diet-induced overweight and obesity and periodontitis risk: An application of the parametric g-formula in the 1982 pelotas birth cohort. Am. J. Epidemiol. 2017, 185, 442-451. [CrossRef]

136. Taubman, S.L.; Robins, J.M.; Mittleman, M.A.; Hernán, M.A. Intervening on risk factors for coronary heart disease: An application of the parametric g-formula. Int. J. Epidemiol. 2009, 38, 1599-1611. [CrossRef] [PubMed]

137. Lajous, M.; Willett, W.C.; Robins, J.; Young, J.G.; Rimm, E.; Mozaffarian, D.; Hernán, M.A. Changes in fish consumption in midlife and the risk of coronary heart disease in men and women. Am. J. Epidemiol. 2013, 178, 382-391. [CrossRef]

138. Danaei, G.; Robins, J.M.; Young, J.; Hu, F.B.; Manson, J.E.; Hernán, M.A. Estimated effect of weight loss on risk of coronary heart disease and mortality in middle-aged or older women: Sensitivity analysis analysis for Unmeasured Confounding by Undiagnosed Disease. Epidemiology 2017, 27, 302-310. [CrossRef]

139. Garcia-Aymerich, J.; Varraso, R.; Danaei, G.; Camargo, C.A.; Hernán, M.A. Incidence of adult-onset asthma after hypothetical interventions on body mass index and physical activity: An application of the parametric g-formula. Am. J. Epidemiol. 2014, 179, 20-26. [CrossRef] [PubMed]

140. Ferguson, J.M.; Costello, S.; Elser, H.; Neophytou, A.M.; Picciotto, S.; Silverman, D.T.; Eisen, E.A. Chronic obstructive pulmonary disease mortality: The Diesel Exhaust in Miners Study (DEMS). Environ. Res. 2020, 180, 108876. [CrossRef]

141. Neophytou, A.M.; Costello, S.; Picciotto, S.; Noth, E.M.; Liu, S.; Lutzker, L.; Balmes, J.R.; Hammond, K.; Cullen, M.R.; Eisen, E.A. Accelerated lung function decline in an aluminium manufacturing industry cohort exposed to pm 2.5: An application of the parametric g-formula. Occup. Environ. Med. 2019, 76, 888-894. [CrossRef]

142. VanderWeele, T.J.; Tchetgen Tchetgen, E.J. Mediation analysis with time varying exposures and mediators. J. R. Stat. Soc. Ser. B Stat. Methodol. 2017, 79, 917-938. [CrossRef]

143. Pinto Pereira, S.M.; De Stavola, B.L.; Rogers, N.T.; Hardy, R.; Cooper, R.; Power, C. Adult obesity and mid-life physical functioning in two British birth cohorts: Investigating the mediating role of physical inactivity. Int. J. Epidemiol. 2020, 49, 845-856. [CrossRef] [PubMed]

144. Islam, T.; Berhane, K.; McConnell, R.; Gauderman, W.J.; Avol, E.; Peters, J.M.; Gilliland, F.D. Glutathione-S-transferase (GST) P1, GSTM1, exercise, ozone and asthma incidence in school children. Thorax 2009, 64, 197-202. [CrossRef] [PubMed]

145. Romieu, I.; Sienra-Monge, J.J.; Ramírez-Aguilar, M.; Moreno-Macías, H.; Reyes-Ruiz, N.I.; Estela del Río-Navarro, B.; Hernández-Avila, M.; London, S.J. Genetic polymorphism of GSTM1 and antioxidant supplementation influence lung function in relation to ozone exposure in asthmatic children in Mexico City. Thorax 2004, 59, 8-10. [PubMed]

146. Gref, A.; Rautiainen, S.; Gruzieva, O.; Håkansson, N.; Kull, I.; Pershagen, G.; Wickman, M.; Wolk, A.; Melén, E.; Bergström, A. Dietary total antioxidant capacity in early school age and subsequent allergic disease. Clin. Exp. Allergy 2017, 47, 751-759. [CrossRef]

147. Limaye, S.; Salvi, S. Obesity and Asthma: The Role of Environmental Pollutants. Immunol. Allergy Clin. North Am. 2014, 34, 839-855. [CrossRef] [PubMed]

148. Romieu, I.; Barraza-Villarreal, A.; Escamilla-Núñez, C.; Texcalac-Sangrador, J.L.; Hernandez-Cadena, L.; Díaz-Sánchez, D.; De Batlle, J.; Del Rio-Navarro, B.E. Dietary intake, lung function and airway inflammation in Mexico City school children exposed to air pollutants. Respir. Res. 2009, 10, 122. [CrossRef] 
149. de Castro Mendes, F.; Paciência, I.; Cavaleiro Rufo, J.; Silva, D.; Cunha, P.; Farraia, M.; Delgado, L.; Garcia-Larsen, V.; Severo, M.; Moreira, A.; et al. The inflammatory potential of diet impacts the association between air pollution and childhood asthma. Pediatr. Allergy Immunol. 2020, 31, 290-296. [CrossRef]

150. Brigham, E.P.; Woo, H.; McCormack, M.; Rice, J.; Koehler, K.; Vulcain, T.; Wu, T.; Koch, A.; Sharma, S.; Kolahdooz, F.; et al. Omega-3 and omega-6 intake modifies asthma severity and response to indoor air pollution in children. Am. J. Respir. Crit. Care Med. 2019, 199, 1478-1486. [CrossRef]

151. Fisher, J.E.; Loft, S.; Ulrik, C.S.; Raaschou-Nielsen, O.; Hertel, O.; Tjønneland, A.; Overvad, K.; Nieuwenhuijsen, M.J.; Andersen, Z.J. Physical activity, air pollution, and the risk of asthma and chronic obstructive pulmonary disease. Am. J. Respir. Crit. Care Med. 2016, 194, 855-865. [CrossRef]

152. Chiolero, A.; Faeh, D.; Paccaud, F.; Cornuz, J. Consequences of smoking for body weight, body fat distribution, and insulin resistance. Am. J. Clin. Nutr. 2008, 87, 801-809. [CrossRef] [PubMed]

153. McEvoy, C.T.; Schilling, D.; Clay, N.; Jackson, K.; Go, M.D.; Spitale, P.; Bunten, C.; Leiva, M.; Gonzales, D.; Hollister-Smith, J.; et al. Vitamin C Supplementation for Pregnant Smoking Women and Pulmonary Function in Their Newborn Infants. JAMA 2014, 311, 2074. [CrossRef]

154. Varraso, R. Nutrition and asthma. Curr. Allergy Asthma Rep. 2012, 12, 201-210. [CrossRef] [PubMed]

155. Guillien, A.; Lepeule, J.; Seyve, E.; Le Moual, N.; Pin, I.; Degano, B.; Garcia-Aymerich, J.; Pépin, J.L.; Pison, C.; Dumas, O.; et al. Profile of exposures and lung function in adults with asthma: An exposome approach in the EGEA study. Environ. Res. 2020, 110422. [CrossRef] [PubMed] 